1

\title{
Chemical Drinking Water Quality in Ghana: Water Costs and Scope for Advanced Treatment
}

Helfrid M.A. Rossiter ${ }^{1}$, Peter A. Owusu ${ }^{2}$, Esi Awuah ${ }^{2}$, Alan M. MacDonald ${ }^{3}$, and Andrea I. Schäfer ${ }^{1 *}$

${ }^{1}$ School of Engineering, The University of Edinburgh, Edinburgh, EH9 3JL, United Kingdom

${ }^{2}$ Department of Civil Engineering, Kwame Nkrumah University of Science and Technology, Kumasi, Ghana

${ }^{3}$ British Geological Survey, Murchison House, West Mains Road, Edinburgh, EH9 3LA, United Kingdom

* Corresponding author phone: +44(0)131 650 7209, fax: +44(0)131 6506781

Email: Andrea.Schaefer@ed.ac.uk

\section{7}


Abstract

To reduce child mortality and improve health in Ghana boreholes and wells are being installed across

26 the country by the private sector, NGOs and the Ghanaian government. Water quality is not generally 27 monitored once a water source has been improved. Water supplies were sampled across Ghana from 28 mostly boreholes, wells and rivers as well as some piped water from the different regions and analysed 29 for the chemical quality. Chemical water quality was found to exceed the WHO guidelines in $38 \%$ of 30 samples, while $\mathrm{pH}$ varied from 3.7 to 8.9. Excess levels of nitrate $\left(\mathrm{NO}_{3}{ }^{-}\right)$were found in $21 \%$ of the 31 samples, manganese $(\mathrm{Mn})$ and fluoride $\left(\mathrm{F}^{-}\right)$in $11 \%$ and $6.7 \%$, respectively. Heavy metals such as lead $(\mathrm{Pb})$, arsenic $(\mathrm{As})$ and uranium $(\mathrm{U})$ were localised to mining areas. Elements without health based guideline values such as aluminium $(\mathrm{Al}, 95 \%)$ and chloride $(\mathrm{Cl}, 5.7 \%)$ were found above the provisional guideline value.

Economic information was gathered to identify water costs and ability to pay. Capital costs of wells and boreholes are about $£ 1200$ and $£ 3800$ respectively. The majority of installation costs are generally paid by government or NGO, while the maintenance is expected to be covered by the community. At

39 least $58 \%$ of the communities had a water payment system in place, either an annual fee/one-off fee or 40 "pay-as-you-fetch". The annual fee was between $£ 0.3-21$, while the boreholes had a water collection 41 fee of $£ 0.07-0.7 / \mathrm{m}^{3}$, many wells were free. Interestingly, the most expensive water $\left(£ 2.9-3.5 / \mathrm{m}^{3}\right)$ was 42 brought by truck. Many groundwater sources were not used due to poor chemical water quality. 43 Considering the cost of unsuccessful borehole development, the potential for integrating suitable water 44 treatment into the capital and maintenance costs of water sources is discussed. Additionally, many 45 sources were not in use due to lack of water capacity, equipment malfunction or lack of economic 46 resources to repair and maintain equipment. Those issues need to be addressed in combination with water quality, coordinated water supply provision and possible treatment to ensure sustainability of improved water resources.

51 Keywords: Ghana, drinking water, improved supply, chemical water quality, boreholes, wells, groundwater, cost 


\section{Introduction}

Approximately 880 million people still lack access to safe drinking water, the lowest coverage found in sub-Saharan Africa. Waterborne diseases, such as diarrhoea, cause 1.5 million deaths a year, prominently to children in developing countries (JMP, 2008). It is estimated that child mortality and could be significantly reduced and general health improved by providing access to safe potable water

60 and improving sanitation and hygiene (WHO, 2004). This is the compelling motivation for

61 governments and aid organisations to avoid acute problems of waterborne diseases by constructing

62 boreholes and wells to improve coverage of safe water sources. However, these new sources, if not 63 adequately monitored, may instead be a source of chronic health problems due to high concentrations 64 of inorganic contaminants such as arsenic (As), fluoride $\left(\mathrm{F}^{-}\right)$and nitrate $\left(\mathrm{NO}_{3}{ }^{-}\right)$(Bissen and Frimmel, 65 2003a; Reimann and Banks, 2004)

66

67 Ghana, in West Africa, celebrated 50 years of independence from colonial rule in 2008, and is often hailed as an African economic and political success (Naylor, 2003). Yet, Ghana is still struggling to provide safe drinking water and sanitation to all its inhabitancy, especially in rural areas (UNICEF, 2007). Although Ghana is doing better than its immediate neighbours (e.g. Côte d'Ivoire and Togo), nearly $12 \%$ of Ghanaian children die before they reach the age of five compared to e.g. $6 \%$ of children in South Africa and $0.6 \%$ of children in the UK (UNICEF, 2007). Access to safe water is an important factor to reduce the number of deaths. According to JMP (2008), 29\% of the rural population rely on unimproved water sources. The majority of the improved sources in rural Ghana are boreholes and protected wells.

77 Ghana has 10 administrative regions: Western Region, Eastern Region, Central Region, Greater Accra,

78 Volta Region, Ashanti Region, Brong-Ahafo, Northern Region, Upper West and Upper East. The 
Final author submission:

Science of the Total Environment 408 (2010) 2378-2386

population according to the last census (2000) was 18.9 million and with a growth rate of bout $2.6 \%$ is estimated at 23 million people (UNICEF, 2007). Although most of the population growth is taking part in cities, the majority of Ghana's population still live in rural areas. Ghana's Water Policy expresses the need to both ensure access to enough safe water to meet basic human needs and at the same time ensure the environmental and financial sustainability of the water source (Government of Ghana, 2007). In an attempt to make the water delivery in the country more effective, Ghana's water supply has, amidst much controversy, been made parastatal (Agyeman, 2007). The Ministry of Water Resources, Works and Housing remains the government institution responsible for water resource management and drinking water supply, while the Ghana Water Company Ltd (GWCL) is in charge of urban water provision. The Community Waste and Sanitation Agency (CWSA) is in charge of facilitating safe water provision and providing technical assistance to the District Assemblies, who are responsible for planning and operation of the water supply to rural communities on a local level (Agyeman, 2007). The CWSA standard is one well or borehole per 300 people. The community are responsible for operation and maintenance. Regional progress reports (Government of Ghana, 2007), report 40-80\% coverage depending on the region; however some organisations and individuals do not operate through the CWSA and thus the total number of improved sources is not accurately known (Nyarko et al., 2009). As the boreholes are constructed, the chemical water quality should be analysed for fluoride $\left(\mathrm{F}^{-}\right)$, manganese $(\mathrm{Mn})$, iron $(\mathrm{Fe})$, magnesium $(\mathrm{Mg})$, calcium $(\mathrm{Ca})$, sulphate $\left(\mathrm{SO}_{4}{ }^{2-}\right)$, arsenic $(\mathrm{As})$, lead $(\mathrm{Pb})$, copper $(\mathrm{Cu})$, nitrate $\left(\mathrm{NO}_{3}{ }^{-}\right)$, nitrite $\left(\mathrm{NO}_{2}{ }^{-}\right)$, chloride $(\mathrm{Cl})$, phosphate $\left(\mathrm{PO}_{4}{ }^{3-}\right)$, aluminium $(\mathrm{Al})$, sodium $(\mathrm{Na})$, zinc $(\mathrm{Zn})$ and alkalinity $\left(\mathrm{CaCO}_{3}\right)$. Water quality is seldom monitored once a borehole has been established due to financial and logistical constraints.

Studies on the water quality in particular problem areas in Ghana have been conducted, such as the northern parts (Pelig-Ba et al., 1991; Pelig-Ba, 1998; Pelig-Ba et al., 2001, 2004), along the coast (Gill, 1996) and in mining areas (Smedley, 1996; Pelig-Ba et al., 2001; Ahmad et al., 2004; Asante et al., 
104 2007; Buamah et al., 2008; Kortatsi et al., 2008b). In these mining areas, elevated concentrations of Fe, $105 \mathrm{Mn}, \mathrm{As}, \mathrm{F}^{-}, \mathrm{Pb}, \mathrm{Hg}$ and $\mathrm{Cr}$ have been found in water sources, soil and air (Kortatsi, 1994; 106 AmonooNeizer et al., 1996; Golow et al., 1996; Obiri et al., 2006; Kortatsi et al., 2008b). Elevated 107 concentrations of $\mathrm{NO}_{3}^{-}$have also been found (Kortatsi et al., 2009), but further study is needed to 108 establish the $\mathrm{NO}_{3}{ }^{-}$distribution in Ghana (British Geological Survey, 2000). Gill (1996) reported 109 brackish water and high concentrations of $\mathrm{Fe}, \mathrm{Mn}, \mathrm{Cl}$ and $\mathrm{NO}_{3}{ }^{-}$in boreholes and wells in the Volta and 110 Upper and Northern regions.

112 The aim of this study was to gain an overview of the chemical water quality of drinking water sources

113 in the country, particularly of "other improved" sources such as wells and boreholes through a survey 114 of rural water supplies. The potential need for further treatment of the water is discussed in the context 115 of current water prices and how treatment and maintenance costs could be incorporated.

\section{2. Materials and methods}

\section{$117 \quad$ 2.1. Sample collection in Ghana}

A total of 230 samples were collected out of which 199 were from improved drinking water sources,

120 mainly boreholes and wells but also some standpipes and trucked water during the 2007 rainy season 121 (July/August) from different regions throughout Ghana. In this paper we analyze the samples from the 122 improved drinking water sources. Where possible the name of the location, age of the water source and 123 pump, funding agency, water charge, money collection system, maintenance arrangements and 124 proximity of other water sources in the area were registered. Difficulties arose when trying to 125 distinguish between boreholes and wells with hand pumps as information on the depth of the source 126 was usually not available. However, the type of pump installed was used as an indication (see Asklund 127 and Eldvall (2005) for a detailed discussion on this problem). Samples were collected from the source 128 in $500 \mathrm{~mL}$ plastic bottles (washed three times with the sample water prior to collection), $20 \mathrm{~mL}$ of it 
Final author submission:

Science of the Total Environment 408 (2010) 2378-2386

129 filtered through a $0.45 \mu \mathrm{m}$ syringe filter (Sartorius Minisart, non-pyrogenic CE) and stored in a $20 \mathrm{~mL}$

130 polypropylene vial. The $\mathrm{pH}$ of the remaining sample was checked upon collection and measured again

131 at the end of the day as was conductivity (Multiline P4 multimeter, WTW) and turbidity (Turbidimeter

132 TN-100, Eutech Instruments). Drinking water was likely to be exposed to the atmosphere before 133 consumption as it was carried back in open basins and buckets and thus this reflects the $\mathrm{pH}$ which 134 would be consumed. Filtered samples were stored at ambient temperature and airlifted to the UK at the 135 completion of the data collection.

\section{$137 \quad$ 2.2. Chemical analysis}

The samples were kept at $4^{\circ} \mathrm{C}$ and separated into two portions. One portion was acidified to $\mathrm{pH}<2$

140 (concentrated Aristar $\mathrm{HNO}_{3}$ ) and left to equilibrate at for at least 3 days before ICP analysis. The other

141 portion was kept untreated at $4^{\circ} \mathrm{C}$ for ion chromatography (IC) analysis. Laboratory blanks were prepared 142 by using MilliQ water and treating it in the same way as the samples. Major cations $(>0.1 \mathrm{mg} / \mathrm{L})$ were 143 detected by inductively coupled plasma-optical emission spectroscopy (ICP-OES) (Perkin Elmer Optima $1445300 \mathrm{DV}, \mathrm{USA})$. Cations of concentrations as low as $0.01 \mu \mathrm{g} / \mathrm{L}$ were analysed with inductively coupled 145 plasma - mass spectroscopy (ICP-MS) (Agilent 7500ce, Japan). Calibrations were verified by a standard 146 reference material (ICP Multi Element Standard Solution VI CertiPUR) and a reference water (SRM 147 1640). Anions were analysed using IC (Dionex, CA, USA).

\section{$148 \quad$ 3. Results and discussion}

\section{$149 \quad$ 3.3. Physico-chemical water quality}

150 The results from the chemical analysis (mean, minimum median, lower inter-quartile range (Q1), 151 median, higher inter-quartile range (Q3) and maximum values) are displayed in Table 1 . The number of 152 samples analysed $(\mathrm{N})$, the applicable WHO drinking water guidelines and the percentage of samples 153 with concentrations out with the guideline values are also presented. The following elements do 
154 currently not have a WHO guideline value: bromium $(\mathrm{Br})$, calcium $(\mathrm{Ca})$, magnesium $(\mathrm{Mg})$, potassium $155(\mathrm{~K})$, sulphur $(\mathrm{S})$, vanadium $(\mathrm{V})$ and cobalt $(\mathrm{Co})$. The following elements did not exceed the WHO 156 guideline value in any location: cadmium $(\mathrm{Cd})$, selenium $(\mathrm{Se})$, Copper $(\mathrm{Cu})$, zinc $(\mathrm{Zn})$, cobalt $(\mathrm{Co})$ and 157 chromium (Cr). The following elements exceeded the health-based WHO guideline value in at least 158 one location: boron $(\mathrm{B})$, manganese $(\mathrm{Mn})$, iron $(\mathrm{Fe})$, arsenic $(\mathrm{As})$, lead $(\mathrm{Pb})$, uranium $(\mathrm{U})$, fluoride $\left(\mathrm{F}^{-}\right)$, 159 nitrate $\left(\mathrm{NO}_{3}{ }^{-}\right)$, sulphate $\left(\mathrm{SO}_{4}{ }^{2-}\right)$ and nickel $(\mathrm{Ni})$. The most widespread parameters exceeding a health 160 based WHO guideline, were $\mathrm{NO}_{3}^{-}(21 \%), \mathrm{Mn}(11 \%)$ and $\mathrm{F}^{-}(6.7 \%)$. Numerous samples exceeded the 161 recommended guidelines based on water treatment considerations or taste for $\mathrm{Al}(95 \%)$ and $\mathrm{Cl}(5.7 \%)$. 162 Turbidity and $\mathrm{pH}$ were also outside the recommended range for $90 \%$ and $53 \%$ of the samples, 163 respectively.

(Table 1)

Sampling locations which contained parameters exceeding the WHO guideline for chemical quality are shown in Figure 1. Only parameters of greatest concern are shown in this map (Fe, $\mathrm{Mn}, \mathrm{F}^{-}, \mathrm{B}, \mathrm{As}, \mathrm{Pb}$, $\mathrm{U}, \mathrm{Cl}$ and $\mathrm{NO}_{3}{ }^{-}$). It is important to note that the concentrations of the analytes are likely to be higher during the dry season (von der Heyden and New, 2004), and hence from a health aspect, the values displayed are conservative since measured during the wet season.

\section{(Figure 1)}

As can be seen in Figure 1, several water sources across the country contain concentrations of inorganic contaminants above the WHO drinking water guideline. Many of the water sources along the coast had elevated TDS, due to proximity to the sea. High concentrations of $\mathrm{NaCl}$ are expected to some extent due to seawater influence. Other ions such as $\mathrm{F}^{-}, \mathrm{Mn}, \mathrm{Fe}$ and $\mathrm{NO}_{3}{ }^{-}$were also above the WHO guideline along the coast. Further inland, a variety of elements exceeded the guideline value, in 
181 particular in the Western, Central, Ashanti and Upper East Regions, where $\mathrm{F}^{-}$and $\mathrm{NO}_{3}{ }^{-}$concentrations 182 exceeded the guideline. Overall $38 \%$ of the samples exceeded the health-based WHO drinking water 183 guidelines for a minimum of one parameter. The graphs of $\mathrm{pH}$, cumulative frequency versus 184 concentration for TDS, conductivity, turbidity and the main inorganic parameters of interest are 185 displayed in Figure 2 to 5. This shows the range of the concentrations found and the percentage of 186 samples found within a certain concentration. The dotted lines mark the WHO drinking water 187 guidelines, where applicable. A more detailed discussion of the individual contaminants found in the waters sources follows.

190 There is no health based guideline for $\mathrm{pH}$, although a range of 6.5-8.5 is often used suggested because 191 aquatic life is negatively affected below pH 6.0 (Mason, 1990). Additionally at low pH, the water is 192 corrosive and can cause wear to equipment. About $50 \%$ of the samples fell outside the recommended $193 \mathrm{pH}$ range, with the majority being too acidic (Figure 2). Acidity is more prominent in environments 194 with granite based rocks with low buffering capacity (Mason, 1990). Of particularly high acidity (pH 195 3.7) was a borehole close to the mining town Obuasi in the Ashanti Region. The borehole also had high 196 concentrations of $\mathrm{Al}, \mathrm{Mn}, \mathrm{Pb}$ and $\mathrm{NO}_{3}{ }^{-}$, indicating contamination from mining. Other acidic waters $(\mathrm{pH}$ 197 4-5.5) were found in the Ashanti, Western and Central Region. Some had high concentrations of Al, $198 \mathrm{Mn}$ or $\mathrm{Pb}$, indicating contamination from mining. These regions are also subject to much mining on 199 both small and large scale. The Western, Central and Ashanti regions would be naturally more acidic 200 both due to their geology (British Geological Survey, 2000) and due to forest coverage (Gill, 1996). 201 Forests are naturally expected to be somewhat acidic, both due to the organic acids from the breakdown 202 of organic matter and the higher precipitation they receive (Spiro and Stigliani, 1996). This same area 203 also receives the highest rainfall in the country $(1500-2200 \mathrm{~mm} / \mathrm{yr}$, compared to $700-1000 \mathrm{~mm} / \mathrm{yr}$ in the 204 northern parts and east coast) (Gill, 1996). 
Final author submission:

208 Turbidity does not have a health based guideline, but it is recommended that it should ideally be below
Science of the Total Environment 408 (2010) 2378-2386

(Figure 2)

\subsection{NTU for effective disinfection (World Health Organisation, 2006). Ninety percent of the samples} were above this guideline (Figure 3) and the turbidity was generally highest in surface waters, although high values (up to 266 NTU) were also found in boreholes. Ghana has set a guideline for a newly drilled bore holes at 5 NTU; and about $80 \%$ of the water sources sampled complied with this value.

\section{(Figure 3)}

Conductivity is an indication of the total dissolved solids (TDS), both organic and inorganic found in the water. There is no health-based guideline. The WHO guideline value of $1200 \mathrm{mg} / \mathrm{L}$ for TDS is based on taste rather than health. High TDS may cause corrosion of equipment such as hand pumps.

\subsection{Parameters of health concern}

The elements analysed for in this study that exceeded a WHO health based guideline value were As, $\mathrm{Pb}, \mathrm{U}, \mathrm{B}, \mathrm{F}^{-}$and $\mathrm{NO}_{3}^{-}$.

The WHO guideline value for arsenic (As) is $10 \mu \mathrm{g} / \mathrm{L}$. Concentrations exceeding this guideline were found in the Ashanti Region, around Obuasi, in the north of the Volta Region and the Upper East (Figure 4). The highest As concentration was in a borehole in Bolgatanga (170 $\mu \mathrm{g} / \mathrm{L})$. Smedley (1996) and Kinniburgh (Smedley, 1996; Smedley and Kinniburgh, 2002) give a detailed description of As geochemistry and its mobility due to weathering conditions. As can for instance be mobilised by flooding and the reduction and mobilisation of As-containing $\mathrm{Fe}$ oxides, or by oxidation of 
Final author submission:

Science of the Total Environment 408 (2010) 2378-2386

231 arsenopyrates, which is the case in the gold mining areas of Ghana (Smedley and Kinniburgh, 2002).

232 Similarly high As concentrations were measured by Asante (2007) in the Tarkwa gold mining region

233 (Western Region). Bolgatanga is an active mining area, and may thus release naturally occurring As.

234 Asante et al. (2007) measured As concentrations in human urine samples of inhabitants of Tarkwa, 235 concluding that the concentrations were similar to those of concentrations found in e.g. Bangladesh and 236 India, although they could not ascertain a link to drinking water. As concentrations in rivers were 237 higher than boreholes, indicating air-borne contamination (Smedley, 1996). Kortatsi et al. (2008b) 238 found that $21 \%$ of the boreholes in the Offin basin (Ashanti Region) contain As concentrations above 239 the WHO guideline. Interestingly, Amonoo-Neizer and Amekor (1993) showed that crops grown close 240 to Obuasi often had double As contents compared to the same crop types grown around Kumasi 241 indicating the release of high concentrations of As in mining areas. Kortatsi (2008a) also identified a 242 number of samples with As concentrations above the drinking water guideline in the Central, Greater 243 Accra and Volta Region. From the results of this study, it does not appear that As is a widespread 244 problem in Ghana, however, it is still important to monitor and regulate contamination from mining 245 activities as very high localised concentrations occur.

(Figure 4)

249 High concentrations of lead $(\mathrm{Pb})$, above the WHO guideline value $10 \mu \mathrm{g} / \mathrm{L}$, were found in the Ashanti 250 region, as well as on the coast. The highest concentration determined was $35 \mu \mathrm{g} / \mathrm{L}$. Concentrations of $251 \mathrm{~Pb}$ above the WHO guideline in wells and boreholes imply that groundwater sources are not 252 necessarily safe from pollution from industrial activities. The high $\mathrm{Pb}$ concentrations found at very low $253 \mathrm{pH}$, and south of Obuasi, indicating acid mine drainage or other mining contamination as a possible 254 source. 
Final author submission:

Science of the Total Environment 408 (2010) 2378-2386

256 Concentrations of uranium (U) above the provisional WHO guideline $(15 \mu \mathrm{g} / \mathrm{L})$ were found in the

257 Central Region and the Volta Region. The Volta Region sample also had high concentrations of $\mathrm{NO}_{3}{ }^{-}$

258 (508 $\mathrm{mg} / \mathrm{L}$, ten times the WHO guideline value), $\mathrm{F}^{-}(4.24 \mathrm{mg} / \mathrm{L}$, nearly three times the guideline value)

259 and $\mathrm{Cl}(500 \mathrm{mg} / \mathrm{L}$, double the taste guideline value). The borehole containing most $\mathrm{U}(267 \mu \mathrm{g} / \mathrm{L})$ was in

260 the Central Region. It did not contain other chemical pollutants. Other boreholes in that area also

261 contained $U$, although below the drinking water guideline value. U was previously found by Dampare

262 (2005). Concentrations below the drinking water guideline were also found in found in the Upper East,

263 indicating that while $\mathrm{U}$ might not be a widespread concern, it may be worth monitoring as it is a natural

264 part of the geology. As well as being naturally radioactive, $U$ is chemically toxic and when ingested 265 may target bones or damage the kidney (The Royal Society, 2002; Kurttio et al., 2005).

267 Boron (B) was found at levels up to $2034 \mu \mathrm{g} / \mathrm{L}$ (the WHO guideline value is $500 \mu \mathrm{g} / \mathrm{L}$ ) in the Northern 268 Region. The highest B concentrations corresponded with alkaline $\mathrm{pH}$. Speciation models of the water 269 (using Minteq 2.53, results not shown), showed B to exist mainly as boric acid $\left(\mathrm{H}_{3} \mathrm{BO}_{3}\right)$ over the acidic 270 to neutral $\mathrm{pH}$ range, and borate $\left(\mathrm{H}_{2} \mathrm{BO}_{3}{ }^{-}\right)$above $\mathrm{pH}$ 8.5. Sources of boron include seawater (unlikely in 271 this situation), coal burning and industrial sources as well as borate-containing fertilizers, which may 272 be the most likely source in this case as there is agricultural activity in the region.

274 About $6.7 \%$ of the samples contained fluoride $\left(\mathrm{F}^{-}\right)$concentrations above the WHO guideline value (1.5 $\mathrm{mg} / \mathrm{L}$ ) (Figure 4). High concentrations of $\mathrm{F}^{-}$were found in the north, but also in many locations along the coast, mainly in wells and boreholes. In the Upper East about $17 \%$ of the samples contained $\mathrm{F}^{-}$ concentrations above the guideline. Boreholes near the coast in the Volta Region contained $\mathrm{F}^{-}$ concentrations of above $4 \mathrm{mg} / \mathrm{L}$, which can cause skeletal fluorosis. Kortatsi (2008b) also found $\mathrm{F}^{-}$ concentrations of $11 \mathrm{mg} / \mathrm{L}$ in the Offin Basin (Ashanti Region). 
Final author submission:

283 Nitrate $\left(\mathrm{NO}_{3}{ }^{-}\right)$has a WHO guideline value of $50 \mathrm{mg} / \mathrm{L}$ and exceeded this concentration in $21 \%$ of the 284 samples (Figure 5). The highest concentration was $508 \mathrm{mg} / \mathrm{L}$. The locations were widespread but 285 mostly found in the Western, Ashanti, southern Volta, Northern region and Upper East. $\mathrm{NO}_{3}{ }^{-}$is 286 regulated as it is one of the causes of methaemoglobinaemia (or "blue-baby syndrome") in infants 287 (Manassaram et al., 2006) as well as a potential risk of stomach cancer (Abrahams, 2002). Forty-seven
Science of the Total Environment 408 (2010) 2378-2386

\section{(Figure 5)}

percent of the well waters had concentrations above the guideline, compared to $16 \%$ of the borehole waters (Figure 6). The concentrations of $\mathrm{NO}_{3}{ }^{-}$were also higher in wells than in surface water (results not shown). This indicates a widespread problem of elevated $\mathrm{NO}_{3}{ }^{-}$in shallow groundwater - probably a result of poor sanitation and latrine construction (MacDonald and Calow, 2009). High levels can also be caused by fertilizer use. The results of Pelig-Ba (2004) confirm those of this study and report a mean of $93.3 \mathrm{mg} / \mathrm{L}$ of $\mathrm{NO}_{3}{ }^{-}$and a maximum of $511 \mathrm{mg} / \mathrm{L}$ in groundwater in the Upper West. The WHO guideline value for nitrite $\left(\mathrm{NO}_{2}{ }^{2-}\right)$ is $0.2 \mathrm{mg} / \mathrm{L}$. Unfortunately $\mathrm{NO}_{2}{ }^{2-}$ needs to be determined within 48 hours, which was not possible due to the logistics. Thus the $\mathrm{NO}_{3}{ }^{-}$values reported in this paper, include any $\mathrm{NO}_{2}{ }^{2-}$ which may have been originally present.

\section{(Figure 6)}

\subsection{Aesthetic parameters}

Parameters analysed for in this study with non-health based WHO guidelines were $\mathrm{Al}, \mathrm{Fe}, \mathrm{Mn}, \mathrm{Cl}$ and $\mathrm{SO}_{4}{ }^{2-}$. Despite not being a health concern, high concentrations affect the quality of water, leading to bad taste and colouration of cooking utensils and food. This has caused hundreds of wells to be abandoned in 
Final author submission:

Science of the Total Environment 408 (2010) 2378-2386

305 favour of surface waters likely contaminated with harmful micro-organisms (Smedley, 1996; Gyau306 Boakye and Dapaah-Siakwan, 1999).

308 The most widespread pollutant was aluminium (Al). The health effects from $\mathrm{Al}$ remain unclear, however, 309 Al does have a practicable non-health based WHO guideline value of $0.2 \mathrm{mg} / \mathrm{L}$ (stated as an achievable 310 level for small water treatment facilities. This takes into consideration the health concerns but also the 311 benefits from using $\mathrm{Al}$ in water treatment (World Health Organisation, 2006)). Ninety-five percent of the 312 samples measured were above the recommended guideline value (Figure 5), several more than ten-fold, 313 with the maximum concentration at $67 \mathrm{mg} / \mathrm{L}$. Areas of particularly high $\mathrm{Al}$ concentration were in the 314 Volta Region (regional average of $27 \mathrm{mg} / \mathrm{L}$ ) where Nkwanta district, Asuogyaman, Hohoe, Keta and 315 Ketu districts had especially high concentrations (average of 30, 42, 28, 55 and $44 \mathrm{mg} / \mathrm{L}$ respectively). 316 The Western Region also had locations containing high Al concentrations, with an average of $13 \mathrm{mg} / \mathrm{L}$ in 317 the Wassa West district. Al may leach from soils unable to buffer acidic precipitation and from minerals 318 such as kaolinite and gibbsite (Langmuir, 1997). Some researchers find high Al concentrations in 319 association with particles (Reimann et al., 2003), in our study however, Al showed no correlation with 320 turbidity. Al concentrations were found to be highest around neutral $\mathrm{pH}$, where $\mathrm{Al}$ normally is less 321 soluble. The high $\mathrm{Al}$ in the samples may possibly be associated with colloids smaller than the $0.45 \mu \mathrm{m}$ 322 filter. Pelig-Ba (2004) also found higher Al concentrations in water at neutral $\mathrm{pH}$ and explained it by 323 presence of chelating agents such as soil organic matter raising the Al solubility. In Pelig-Ba's study from 324 the Upper Regions (1998) the Al range was reported as up to $47 \mathrm{mg} / \mathrm{L}$, with a mean of $4.4 \mathrm{mg} / \mathrm{L}$ in the 325 Northern Region.

327 A number of samples had very high sulphate $\left(\mathrm{SO}_{4}{ }^{2-}\right)$ concentrations $(>500 \mathrm{mg} / \mathrm{L})$ (Figure 5). One was 328 found in a relatively new borehole in the Northern Region, probably due to mudstone geology. In this 329 sample high Mn concentrations were also found. Due to the taste, consumers preferred to drink water 
Final author submission:

Science of the Total Environment 408 (2010) 2378-2386

330 from the nearby shallow well, which contained low $\mathrm{SO}_{4}{ }^{2-}$ and $\mathrm{Mn}$ concentrations but possible

331 microbiological contamination. This illustrates how poor chemical water quality of new deeper

332 groundwater sources may drive people back to shallow contaminated sources. Another borehole from

333 the same region contained similar $\mathrm{SO}_{4}{ }^{2-}$ and TDS levels, but no Mn, and people were happy to drink

334 the water.

336 Around $5.7 \%$ of the waters sampled contain more chloride $(\mathrm{Cl})$ than the recommended value $(250$ $337 \mathrm{mg} / \mathrm{L}$ ) (Figure 5). This value is based on taste, but waters of these $\mathrm{Cl}$ concentrations are also more 338 corrosive. As can be seen from the map in Figure 1, much of the high $\mathrm{Cl}$ concentrations are found in 339 the Volta delta and along the coast. Gill et al. (1996) also reported high Cl concentrations in the Keta 340 district and found similar evidence of seawater intrusion. A study conducted by Kortatsi (2006) in the 341 Accra plains similarly found high concentrations of $\mathrm{Cl}$ and concluded that $75 \%$ of the boreholes in the 342 area were brackish (TDS range $1000-10000 \mathrm{mg} / \mathrm{L}$ ), with $\mathrm{Na}$ and $\mathrm{Cl}$ as the dominating ions.

344 Iron $(\mathrm{Fe})$ concentrations below $2000 \mu \mathrm{g} / \mathrm{L}$ are described as safe by the WHO (Figure 4), although taste 345 is affected above $300 \mu \mathrm{g} / \mathrm{L}$. This taste based value is used by many studies when reporting Fe. Up to $3464257 \mu \mathrm{g} / \mathrm{L}$ was measured. As can be seen from the map (Figure 1), high Fe concentrations were found 347 in a variety of locations along the coast, inland in forested areas and the Northern Region. Most 348 samples (97.4\%) fall below $300 \mu \mathrm{g} / \mathrm{L}$ and $99 \%$ are below the guideline value $2000 \mu \mathrm{g} / \mathrm{L}$ (Figure 4).

349 Most of the sources containing very high Fe concentrations were found in boreholes. The chemistry of 350 naturally occuring $\mathrm{Fe}$ is controlled by the redox conditions of the water (not measured due to lack of 351 equipment), where $\mathrm{Fe}$ is mobilised under reducing conditions, indicating that the environment of these 352 boreholes was reducing. 
Final author submission:

Science of the Total Environment 408 (2010) 2378-2386

354 Concentrations of manganese $(\mathrm{Mn})$ above the WHO drinking water guideline value $(400 \mu \mathrm{g} / \mathrm{L})$ were

355 found mainly the Western and Ashanti region and along the coast (Figure 1). The highest 356 concentrations were found in boreholes (Figure 6). Similarly to $\mathrm{Fe}, \mathrm{Mn}$ chemistry is also redox 357 controlled. High concentrations of $\mathrm{Fe}$ and $\mathrm{Mn}$ corresponded in some samples, but for the majority of 358 them high Mn concentrations were not accompanied by high Fe concentrations.

360 High concentrations of calcium $(\mathrm{Ca})$, magnesium $(\mathrm{Mg})$ and potassium $(\mathrm{K})$ (Figure 5) are generally not 361 a health concern and thus do not have guideline values set by the WHO, but are important nutrients. 362 Studies have shown an inverse relationship between cardiovascular disease and water hardness, with 363 increased risk occurring with $\mathrm{Ca}$ concentrations $<60 \mathrm{mg} / \mathrm{L}$ of $\mathrm{Ca}$ (Packham, 1990). In fact the water 364 sources in Ghana were relatively soft and the concentrations of the samples in the third percentile were 365 below $15 \mathrm{mg} / \mathrm{L}$ for $\mathrm{Mg}$ and $40 \mathrm{mg} / \mathrm{L}$ for $\mathrm{Ca}$ (Table 1). In large concentrations however, they may affect 366 the taste of the water by contributing to high TDS, which will also affect practical water usage 367 (washing with soap).

369 In summary, the water quality from the different sources in Ghana displayed a wide range of chemical 370 water quality, with many sources containing concentrations above the drinking water guidelines. In 371 boreholes high concentrations of $\mathrm{NO}_{3}{ }^{-}, \mathrm{F}^{-}, \mathrm{B}, \mathrm{Pb}, \mathrm{As}, \mathrm{U}, \mathrm{Cl}, \mathrm{Fe}, \mathrm{Mn}$ and $\mathrm{SO}_{4}{ }^{2-}$, and high levels turbidity 372 were found. In wells $\mathrm{NO}_{3}^{-}, \mathrm{Fe}$ and turbidity were common problems, as well as some instances of As, $373 \mathrm{Mn}, \mathrm{Cl}$ and $\mathrm{F}^{-}$.

\section{6. $\quad$ Current rural water sources, costs and ability to pay}

376 The Ghana Water Policy advocates provision of demand driven basic water and sanitation services for 377 communities that contribute towards capital cost, operation, maintenance and repairs (Government of 
Final author submission:

Science of the Total Environment 408 (2010) 2378-2386

378 Ghana, 2007). Non-government organisations often support the communities by paying up to $95 \%$ of

379 the borehole cost, while the community raises $5 \%$ of the borehole cost (Government of Ghana, 2007).

About $25 \%$ of the communities visited had an annual user fee per household ranging from 5000 to 40000 cedis ( $£ 0.3-£ 21$, August 2007). About $33 \%$ of the water supplies had a water collection charge based on quantity of water collected (Figure 7). Surface and many well waters were often free of charge while boreholes, piped and especially truck-delivered water attracted the highest charges. The cost per bucket (18L) for boreholes and piped water ranged from 25 to 250 cedis $\left(£ 0.07\right.$ to $£ 0.7 / \mathrm{m}^{3}$, based on 62 communities) and the cost per basin (40L) ranged from 50 to 500 cedis $\left(£ 0.07\right.$ to $£ 0.7 / \mathrm{m}^{3}$, based on 47 communities). Where water was trucked in, the cost was 1000-1200 cedis per bucket (£2.9-3.5/ $\mathrm{m}^{3}$, based on two communities). An appointed water vendor from the WatSan committee was often situated at the water source to directly collect the payment from the users. Understandably some

390 households choose to use cheaper or free water sources for washing and bathing, increasing the risk of 391 contact with diseases transmitted by surface water. Surface water is often used during the rainy season 392 due to availability while in dry seasons they may be used if borehole re-charge is low (Iten and 393 McCarron, 2006). 13\% of the communities visited did not have an operational payment system in 394 place. Many communities were therefore struggling to raise between 1.5-2.5 million cedis (about £80$395 £ 130$ ) in order to pay for repairs or spare parts of pumps, broken a couple of years earlier. When this proved to be a major hurdle and pumps would remain disused or even abandoned. Another problem

397 encountered in some communities was that there was no payment system for the trained community 398 members to get paid for maintenance services, which meant that they were unwilling to assist. 399 Organising maintenance and collecting payment for repairs is further complicated by the dynamic 400 movement of people between different communities and even parts of the country (Iten and McCarron, 401 2006). In some cases pumps were ill designed, causing unaffordable chronic failure of parts. 
403

404

405

406

407

408

409

\section{(Figure 7)}

\subsection{Is water treatment a suitable option for sources of poor chemical quality?}

The problems encountered in the survey were those of high turbidity, high concentrations of $\mathrm{F}^{-}, \mathrm{NO}_{3}^{-}$, $\mathrm{Al}, \mathrm{Mn}, \mathrm{Fe}$ and localised contamination of $\mathrm{Pb}, \mathrm{As}, \mathrm{B}$ and $\mathrm{U}$. Overall, 38\% of the sources analysed exceeded a health-based WHO guideline for chemical parameters. Installation costs of boreholes and wells are about $£ 3800$ and $£ 1800$, respectively. Many boreholes fail due to the high chemical content of for example $\mathrm{F}^{-}$(Smedley et al., 2002) and up to $64 \%$ of the boreholes in the north of Ghana fail based on water flow, re-charge and chemical quality (Iten and McCarron, 2006). Thus for the actual costs of developing ground water the number of unsuccessful boreholes drilled need to be taken into account. To reduce this cost in areas of complex geology, investment in initial hydrogeological investigations is important to improve success (MacDonald and Calow, 2009). An alternative option to capping existing boreholes and drilling new, potentially unsuccessful boreholes would be to treat the water. Suitable treatment options in developing countries can be provided as centralised, community based or point-ofuse/household based approaches. For economic and infrastructural reasons, community based or pointof-use treatments are considered preferable to centralised treatment for rural communities (PeterVarbanets et al., 2009). This also applies to rural areas of Ghana where boreholes or wells may already exist while access to a centralised supply does not. Treatment technologies considered suitable for developing countries, such as sand filtration, UV disinfection (SODIS), ceramic filters and chlorination mainly remove or destroy microbial pathogens and turbidity (Sobsey et al., 2008; Peter-Varbanets et al., 2009) and could potentially be used to disinfect surface waters of good chemical quality, but do not effectively remove chemical contaminants. Importantly, over $90 \%$ of the samples had a turbidity of more than 0.1 NTU, which must be reduced before disinfection can be effective. 
Final author submission:

Science of the Total Environment 408 (2010) 2378-2386

429 Treatment methods which target chemical contaminants combine processes such as adsorption or 430 coagulation with ultrafiltration or sandfiltration processes (Brandhuber and Amy, 2001; Johnston and 431 Heijnen, 2001; Chakravarty et al., 2002). Issues of handling, cost of chemicals, sanitation and 432 regeneration of the adsorption materials are a concern. Ultrafiltration systems are available at an 433 investment cost of about $£ 2000$ ( $20 \mathrm{~m}^{3} /$ day capacity), and are maintained by a daily washing. Low-cost 434 As removal for communities in developing countries have been investigated (Bissen and Frimmel, 435 2003b; Malik et al., 2009) and wells can even be constructed to allow re-circulation of oxidised water 436 back into the source, thus oxidising and immobilising Fe and As before it is with-drawn (van Halem et 437 al., 2009). This method still requires further development and testing, however, and the resulting 438 concentrations depend on concentrations originally present. The need to remove a variety of chemical 439 contaminants from existing water sources persists and long-term studies are lacking. The issue of $\mathrm{F}^{-}$ 440 removal from drinking water in the northern regions of Ghana, for example, is unresolved (CWSA, 441 2007). In such situations membrane technologies have unique potential due to their physical separation.

442 Nanofiltration or reverse osmosis are well adapted in developed countries for water desalination, reuse 443 and removal of dissolved contaminants while application in developing countries has not yet widely 444 progressed. Investment cost into single tap reverse osmosis has been estimated to $£ 190-£ 380$ (Peter445 Varbanets et al., 2009) which may be an option if it could be developed for boreholes. A solar powered 446 community-based membrane system was field tested by Schäfer et al. (2007) and found to perform 447 well in terms of potable water production. The system had a specific energy consumption of 1.2 $448 \mathrm{kWh} / \mathrm{m}^{3}$. Investment and maintenance costs into a solar powered electrodialysis systems have been 449 calculated as $£ 0.15-0.28 / \mathrm{m}^{3}$, with an initial investment of at least $£ 5400$ (Ortiz et al., 2008). However, 450 the long-term integration of operation and maintenance of such systems into communities requires 451 solid strategies at a local level. 


\section{8. $\quad$ Sustainability of treatment systems}

454 The effectiveness and sustainability of point-of-use and small-scale water treatment technology 455 remains to be seen as contentious (see for example Hunter (in press), Hunter et al. (2009) and Schmidt 456 and Cairncross (in press)). Three components of sustainability for engineered solutions in developing 457 countries were identified by Montgomery et al. (2009) as 1) effective community demand, 2) local 458 financing and cost recovery, and 3) dynamic operation and maintenance. The importance of local 459 ownership of both the technology development (local sourcing and production) as well as the resulting 460 systems should be emphasized. Failure to incorporate these components into a water source and 461 potential water treatment reduce the likelihood of its long-term functionality. Cost recovery of five 462 community managed water systems in the Ashanti Region was investigated by Nyarko et al. (2007), 463 who found that neither of the communities recovered their full capital and operational costs, while four 464 out of five recovered their operation and maintenance costs. Interview results showed that there was not 465 an understanding amongst the community members of the full costs involved, while some preferred to 466 use free untreated water sources when the prices were too high. The importance of demand-driven 467 appropriate water treatment was high-lighted in a study by Hoque et al. (2004). They found that 468 household treatment systems often were abandoned after a short period, while community based 469 systems proved more sustainable. For this reason it is important to understand the willingness (and 470 ability) to pay for water provision in such communities as well as elucidating the most suitable 471 treatment option.

\section{4. Conclusions}

474 It was found in this study that $38 \%$ of the wells and boreholes in Ghana had high concentrations of 475 inorganic contaminants. Major problems identified were that of high turbidity, low $\mathrm{pH}$, high 476 concentrations of $\mathrm{NO}_{3}{ }^{-}, \mathrm{F}^{-}, \mathrm{Al}$ and $\mathrm{Cl}$ and in localised areas $\mathrm{As}, \mathrm{Pb}, \mathrm{B}$ and $\mathrm{U}$. The importance of regular 
Final author submission:

Science of the Total Environment 408 (2010) 2378-2386

477 monitoring of groundwater sources is emphasized. While some 'low-cost' treatment technologies to 478 remove, for instance, As and $\mathrm{F}^{-}$exist, the long-term sustainability and management of such 479 technologies is yet to be proven for a wide range of chemical contaminants and how performance (in 480 particular contaminant breakthrough) can be monitored. The maintenance costs of systems could 481 potentially be incorporated in the maintenance costs currently paid by community members (up to $482 £ 0.7 / \mathrm{m}^{3}$ ), especially if government and NGO's were willing to invest in the capital costs. This could be 483 worthwhile, considering the cost of unsuccessful boreholes. About $58 \%$ of the communities had a 484 payment system in place to recover basic maintenance costs.

486 In areas of high chemical contamination more advanced inorganic removal treatment such as 487 nanofiltration and reverse osmosis may be necessary. This would require extensive training in 488 operation and maintenance, but while initial investment would increase, it may facilitate maintenance 489 and potentially reduce long-term costs in particular if renewable energy is used as a power supply. 490 Given that renewable energy powered ground water pumps are rapidly penetrating the market and 491 water charges for trucked water is comparable to membrane treatment costs this is a most viable option. 492 Any form of improved water supply requires community ownership and commitment by local and 493 national authorities to ensure that long-term needs are met. Research into ensuring long-term 494 sustainability in terms of community demand, cost recovery, failure management, maintenance of 495 water sources and treatment needed is timely and of critical importance.

\section{5. Acknowledgements}

498 UNESCO Scotland are thanked for project funding, the Royal Society and the Royal Academy of 499 Engineering for travel support. A studentship from EPSRC and ESRC was provided for H.M.A. Rossiter. 500 Mr. Samuel Ansere is thanked for his superb local guidance in Ghana as the driver of the team during the 
Final author submission:

Science of the Total Environment 408 (2010) 2378-2386

501 field trip in summer 2007 and KNUST for the provision of a vehicle. Tanya Peshkur and Dr Peter

502 Anderson assisted with IC analysis, and Dr Lorna Eades for assistance with ICP-MS (all University of

503 Edinburgh).

504 Prof. Bryce Richards (Heriot Watt University) is thanked for his active participation in the sampling

505 trip, while Björn Schulte-Herbrüggen as well as Kofi Awuah who provided some remote samples.

506 Faustina Atipoka (CWSA, Bongo district), Osmund Ansa-Ansare (WRI, Accra), Hajo Schäfer (IGIP

507 Consulting Engineers, Kumasi) are thanked for helpful discussions in conjunction with field trip

508 logistics. Gloria Addicio (University of Hull) provided the map modified for the paper. Prof.

509 Menachem Elimelech (Yale University) has critically reviewed the manuscript and Annalisa DeMunari

510 and Laura Richards (University of Edinburgh) are thanked for critical proof reading.

\section{References}

513

514

515

516

517

518

519

520

521

522

523

524

525

526

527

528

529

530

531

532

533

534

Abrahams PW. Soils: their implications to human health. Sci Total Environ 2002; 291: 1-32.

Agyeman K. Privatization of water in Ghana: stopped in its tracks or a strategic pause? Int J Environ Stud 2007; 64: 525-536.

Ahmad K, Dampare SB, Adomako D, Opata NN, Quagraine RE. The use of neutron activation analysis in gold prospecting in small-scale mining in Ghana. J Radioanal Nucl Chem 2004; 260: 653658.

AmonooNeizer EH, Amekor EMK. Determination of Total Arsenic in Environmental-Samples from Kumasi and Obuasi, Ghana. Environ Health Perspect 1993; 101: 46-49.

AmonooNeizer EH, Nyamah D, Bakiamoh SB. Mercury and arsenic pollution in soil and biological samples around the mining town of Obuasi, Ghana. Water Air Soil Pollut 1996; 91: 363-373.

Asante KA, Agusa T, Subramanian A, Ansa-Asare OD, Biney CA, Tanabe S. Contamination status of arsenic and other trace elements in drinking water and residents from Tarkwa, a historic mining township in Ghana. Chemosphere 2007; 66: 1513-1522.

Asklund R, Eldvall B. Contamination of water resources in Tarkwa mining area of Ghana. Department of Engineering Geology 2005; M.Sc.: 57.

Bissen M, Frimmel FH. Arsenic - a review. - Part 1: Occurrence, toxicity, speciation, mobility. Acta Hydroch Hydrob 2003a; 31: 9-18.

Bissen M, Frimmel FH. Arsenic - a review. Part II: Oxidation of arsenic and its removal in water treatment. Acta Hydroch Hydrob 2003b; 31: 97-107.

Brandhuber P, Amy G. Arsenic removal by a charged ultrafiltration membrane-influences of membrane operating conditions and water quality on arsenic rejection. Desalination 2001; 140: 1-14. 
Final author submission:

British Geological Survey. 2000. Groundwater quality: Ghana. www.bgs.ac.uk/downloads/start.cfm?id=1281, 2009, November

Buamah R, Petrusevski B, Schippers JC. Presence of arsenic, iron and manganese in groundwater within the gold-belt zone of Ghana. Journal of Water Supply Research and Technology-Aqua 2008; 57: 519-529.

Chakravarty S, Dureja V, Bhattacharyya G, Maity S, Bhattacharjee S. Removal of arsenic from groundwater using low cost ferruginous manganese ore. Water Research 2002; 36: 625-632.

CWSA. Summary of the fluoride issues in the northern region, 2007.

Dampare SB, Nyarko BJB, Osae S, Akaho EHK, Asiedu DK, Serfor-Armah Y, et al. Simultaneous determination of tantalum, niobium, thorium and uranium in placer columbite-tantalite deposits from the Akim Oda District of Ghana by epithermal instrumental neutron activation analysis. J Radioanal Nucl Chem 2005; 265: 53-59.

Gill HE. A groundwater Reconnaissance of the Republic of Ghana, with description of geohydrolic provinces. US Geol Surv Water Supply Pap 1996; 1757-k.

Golow AA, Schlueter A, AmihereMensah S, Granson HLK, Tetteh MS. Distribution of arsenic and sulphate in the vicinity of Ashanti Goldmine at Obuasi, Ghana. Bull Environ Contam Toxicol 1996; 56: 703-710.

Government of Ghana. National Water Policy. In: Ministry of Water Resources WaH, editor, 2007.

Gyau-Boakye P, Dapaah-Siakwan S. Groundwater: Solution to Ghana's Rural Water Supply Industry? the Ghana Engineer 1999; May.

Hoque BA, Hoque MM, Ahmed T, Islam S, Azad AK, Ali N, et al. Demand-based water options for arsenic mitigation: an experience from rural Bangladesh. Public Health 2004; 118: 70-77.

Hunter PR. Household water treatment in developing countries: comparing different intervention types using meta-regression. Environ. Sci. Technol. in press.

Hunter PR, Zmirou-Navier D, Hartemann P. Estimating the impact on health of poor reliability of drinking water interventions in developing countries. Sci Total Environ 2009; 407: 2621-2624.

Iten S, McCarron P. Buried in Boreholes. Department of Environment, Technology and Social Studies 2006; M.Sc. Technological and Socio-Economic Planning: 306.

JMP. Progress on drinking water and sanitation: special focus on sanitation WHO, Geneva and UNICEF, New York, World Health Organisation and United Nations Childre's Fund Joint Monitoring Programme for Water Supply and Sanitation (JMP), 2008.

Johnston R, Heijnen H. Safe water technology for arsenic removal. International workshop on technologies for arsenic removal from drinking water, Bangladesh University of Engineering and Technology, Dhaka, India, 2001.

Kortatsi BK. Groundwater Utilization in Ghana. Future Groundwater Resources at Risk 1994: 149-156.

Kortatsi BK. Hydrochemical characterization of groundwater in the Accra plains of Ghana. Environ Geol 2006; 50: 299-311.

Kortatsi BK, Anku YSA, Anornu GK. Characterization and appraisal of facets influencing geochemistry of groundwater in the Kulpawn sub-basin of the White Volta Basin, Ghana. Environ Geol 2009; 58: 1349-1359.

Kortatsi BK, Asigbe J, Dartey GA, Tay CK, Anornu G, Hayford E. Reconnaissance survey of arsenic concentration in groundwater in south-eastern Ghana. West Afr J Appl Ecol 2008a; 13.

Kortatsi BK, Tay CK, Anornu G, Hayford E, Dartey GA. Hydrogeochemical evaluation of groundwater in the lower Offin basin, Ghana. Environ Geol 2008b; 53: 1651-1662.

Kurttio P, Komulainen H, Leino A, Salonen L, Auvinen A, Saha H. Bone as a possible target of chemical toxicity of natural uranium in drinking water. Environ Health Perspect 2005; 113: 6872 .

Langmuir D. Aqueous Environmental Geochemistry. Upper Saddle River, Prentice Hall, 1997, 600. 
Final author submission:

MacDonald AM, Calow RC. Developing groundwater for secure rural water supplies in Africa. Desalination 2009; 248: 546-556.

Malik AH, Khan ZM, Mahmood Q, Nasreen S, Bhatti ZA. Perspectives of low cost arsenic remediation of drinking water in Pakistan and other countries. J Hazard Mater 2009; 168: 1-12.

Manassaram DM, Backer LC, Moll DM. A review of nitrates in drinking water: Maternal exposure and adverse reproductive and developmental outcomes. Environ Health Perspect 2006; 114: 320327.

Mason CF. Biological aspects of freshwater pollution. In: Harrison RM, editor. Pollution: causes, effects and control. the Royal Society of Chemistry, Cambridge, 1990, pp. 108-111.

Montgomery MA, Bartram J, Elimelech M. Increasing Functional Sustainability of Water and Sanitation Supplies in Rural Sub-Saharan Africa. Environ Eng Sci 2009; 26: 1017-1023.

Naylor R. Ghana An Oxfam Country Profile. Oxford, Oxfam, 2003.

Nyarko KB, Awuah E, Ofori D. Local initiative in community water supply: Case study in Ashanti Region, Ghana. Desalination 2009; 248: 650-657.

Nyarko KB, Oduro-Kwarteng S, Adama I. Cost recovery of community-managed piped water systems in Ashanti region, Ghana. Water and Environment Journal 2007; 21: 92-99.

Obiri S, Dodoo DK, Okai-Sam F, Essumang DK. Cancer health risk assessment of exposure to arsenic by workers of AngloGold Ashanti-Obuasi gold mine. Bull Environ Contam Toxicol 2006; 76: 195-201.

Ortiz JM, Exposito E, Gallud F, Garcia-Garcia V, Montiel V, Aldaz A. Desalination of underground brackish waters using an electrodialysis system powered directly by photovoltaic energy. Solar Energy Materials and Solar Cells 2008; 92: 1677-1688.

Packham RF. Water quality and health. In: Harrison RM, editor. Pollution: causes, effects and control. the Royal Society of Chemistry, Cambridge, 1990, pp. 83-97.

Pelig-Ba KB. Trace elements in groundwater from some crystalline rocks in the Upper Regions of Ghana. Water Air Soil Pollut 1998; 103: 71-89.

Pelig-Ba KB, Biney CA, Antwi LA. Trace-Metal Concentrations in Borehole Waters from the Upper Regions and the Accra Plains of Ghana. Water Air Soil Pollut 1991; 59: 333-345.

Pelig-Ba KB, Parker A, Price M. Elemental contamination of rainwater by airborne dust in Tamale Township area of the northern region of Ghana. Environ Geochem Health 2001; 23: 333-346.

Pelig-Ba KB, Parker A, Price M. Trace element geochemistry from the Birrimian metasediments of the Northern Region of Ghana. Water Air Soil Pollut 2004; 153: 69-93.

Peter-Varbanets M, Zurbruegg C, Swartz C, Pronk W. Decentralized systems for potable water and the potential of membrane technology. Water Research 2009; 43: 245-265.

Reimann C, Banks D. Setting action levels for drinking water: Are we protecting our health or our economy (or our backs!)? Sci Total Environ 2004; 332: 13-21.

Reimann C, Bjorvatn K, Frengstad B, Melaku Z, Tekle-Haimanot R, Siewers U. Drinking water quality in the Ethiopian section of the East African Rift Valley I - data and health aspects. Sci Total Environ 2003; 311: 65-80.

Schäfer AI, Broeckmann A, Richards BS. Renewable energy powered membrane technology 1. development and characterisation of a photovoltaic hybrid membrane system. Environmental Science and Technology 2007; 41: 998-1003.

Schmidt W-P, Cairncross S. Household water treatment in poor populations: Is there enough evidence for scaling up now? Environ. Sci. Technol. in press.

Smedley PL. Arsenic in rural groundwater in Ghana. J Afr Earth Sci 1996; 22: 459-470.

Smedley PL, Kinniburgh DG. A review of the source, behaviour and distribution of arsenic in natural waters. Appl Geochem 2002; 17: 517-568.

Smedley PL, Nkotagu H, Pelig-Ba KB, MacDonald AM, Tyler-Whittle R, Whitehead EJ, et al. Fluoride in groundwater from high-fluoride areas of Ghana and Tanzania 'Minimising fluoride 
in drinking water in problem aquifers' R8033. Phase I Final Report. Keyworth, Nottingham, British Geological Survey 2002, 1-72.

Sobsey MD, Stauber CE, Casanova LM, Brown JM, Elliott MA. Point of use household drinking water filtration: A practical, effective solution for providing sustained access to safe drinking water in the developing world. Environmental Science \& Technology 2008; 42: 4261-4267. Hall, 1996.

The Royal Society. The health effects of depleted uranium munitions: a summary. Journal of Radiological Protection 2002; 22: 131-139.

UNICEF. The State of the World's Children 2008: Child Survival. New York, USA, 2007.

van Halem D, Heijman SGJ, Amy GL, van Dijk JC. Subsurface arsenic removal for small-scale application in developing countries. Desalination 2009; 248: 241-248.

von der Heyden CJ, New MG. Groundwater pollution on the Zambian Copperbelt: deciphering the source and the risk. Sci Total Environ 2004; 327: 17-30.

WHO. Guidelines for Drinking Water Quality, 2004.

World Health Organisation. Guidelines for drinking water quality: first addendum to third edition. Geneva, 2006, 515. 
Final author submission:

652 Table 1 Distribution of measured parameters in the samples. The minimum, mean, maximum and 653 median values are given along with the WHO guideline values and the percentage of samples which 654 exceeded the guideline value.

\begin{tabular}{|c|c|c|c|c|c|c|c|c|c|c|}
\hline Parameter & Unit & $\mathbf{N}$ & Mean & Min & Q1 & Median & Q3 & Max & $\begin{array}{l}\text { WHO } \\
\text { guide- } \\
\text { line }\end{array}$ & $\begin{array}{c}\% \\
\text { outwith } \\
\text { guide- } \\
\text { line }\end{array}$ \\
\hline $\mathrm{Al}$ & $\mathrm{mg} / \mathrm{L}$ & 192 & 11.87 & $<0.020$ & 3.927 & 8.500 & 14.60 & 66.69 & $0.2^{*}$ & 95 \\
\hline As & $\mu \mathrm{g} / \mathrm{L}$ & 195 & 1.930 & $<0.003$ & $<0.003$ & 0.073 & 0.532 & 169.5 & 10 & 0.5 \\
\hline B & $\mu \mathrm{g} / \mathrm{L}$ & 195 & 61.11 & $<2.551$ & 5.820 & 10.08 & 27.14 & 2034 & 500 & 2.6 \\
\hline $\mathrm{Br}$ & $\mathrm{mg} / \mathrm{L}$ & 193 & 0.029 & $<0.200$ & $<0.200$ & $<0.200$ & $<0.200$ & 1.116 & - & - \\
\hline $\mathrm{Ca}$ & $\mathrm{mg} / \mathrm{L}$ & 192 & 28.59 & 0.091 & 10.411 & 19.70 & 39.61 & 169.4 & - & - \\
\hline $\mathrm{Cd}$ & $\mu \mathrm{g} / \mathrm{L}$ & 195 & 0.025 & $<0.001$ & $<0.001$ & $<0.001$ & 0.013 & 1.755 & 3 & - \\
\hline $\mathrm{Cl}$ & $\mathrm{mg} / \mathrm{L}$ & 193 & 49.44 & $<0.200$ & 3.711 & 13.27 & 41.22 & 597.2 & $250^{*}$ & 5.7 \\
\hline $\mathrm{Co}$ & $\mu \mathrm{g} / \mathrm{L}$ & 195 & 0.262 & $<0.051$ & $<0.051$ & $<0.051$ & 0.077 & 11.62 & - & - \\
\hline $\mathrm{Cr}$ & $\mu \mathrm{g} / \mathrm{L}$ & 195 & 0.199 & $<0.068$ & $<0.068$ & $<0.068$ & 0.151 & 9.290 & 50 & - \\
\hline $\mathrm{Cu}$ & $\mu \mathrm{g} / \mathrm{L}$ & 195 & 2.774 & $<0.173$ & $<0.173$ & $<0.173$ & 0.715 & 83.10 & 2000 & - \\
\hline $\mathrm{F}^{-}$ & $\mathrm{mg} / \mathrm{L}$ & 193 & 0.470 & $<0.100$ & 0.044 & 0.209 & 0.45 & 4.238 & 1.5 & 6.7 \\
\hline $\mathrm{Fe}$ & $\mu \mathrm{g} / \mathrm{L}$ & 195 & 84.73 & $<0.001$ & 5.446 & 17.78 & 46.16 & 4257 & $\begin{array}{l}2000^{\mathrm{a}} \\
\left(300^{*}\right)\end{array}$ & $\begin{array}{c}1.0 \\
(2.6)\end{array}$ \\
\hline $\mathrm{K}$ & $\mathrm{mg} / \mathrm{L}$ & 187 & 4.382 & 0.241 & 1.475 & 2.564 & 5.511 & 29.65 & - & - \\
\hline $\mathrm{Mg}$ & $\mathrm{mg} / \mathrm{L}$ & 192 & 10.52 & $<0.030$ & 2.586 & 6.459 & 14.55 & 66.20 & - & - \\
\hline $\mathrm{Mn}$ & $\mu \mathrm{g} / \mathrm{L}$ & 195 & 134.8 & 0.030 & 4.447 & 19.21 & 117.9 & 2051 & 400 & 11 \\
\hline $\mathrm{Ni}$ & $\mu \mathrm{g} / \mathrm{L}$ & 195 & 0.579 & $<0.054$ & $<0.054$ & $<0.054$ & 0.436 & 29.59 & 20 & 0.5 \\
\hline $\mathrm{NO}_{3}^{-}$ & $\mathrm{mg} / \mathrm{L}$ & 193 & 34.01 & $<0.200$ & 0.514 & 6.394 & 31.52 & 507.7 & 50 & 21 \\
\hline $\mathrm{Pb}$ & $\mu \mathrm{g} / \mathrm{L}$ & 195 & 1.526 & $<0.006$ & 0.489 & 0.946 & 1.517 & 34.94 & 10 & 1.5 \\
\hline $\mathrm{PO}_{4}^{2-}$ & $\mathrm{mg} / \mathrm{L}$ & 193 & 0.058 & $<0.100$ & $<0.10$ & $<0.100$ & $<0.100$ & 1.214 & - & - \\
\hline $\mathrm{S}$ & $\mathrm{mg} / \mathrm{L}$ & 192 & 6.905 & $<0.200$ & 0.372 & 1.150 & 4.091 & 235.4 & - & - \\
\hline $\mathrm{Se}$ & $\mu \mathrm{g} / \mathrm{L}$ & 195 & 0.434 & $<0.306$ & $<0.306$ & $<0.306$ & 0.598 & 6.175 & 10 & \\
\hline $\mathrm{SO}_{4}^{2-}$ & $\mathrm{mg} / \mathrm{L}$ & 193 & 34.69 & $<0.200$ & 1.648 & 5.236 & 23.75 & 931.4 & $500^{\mathrm{b}}$ & 1.0 \\
\hline $\mathrm{U}$ & $\mu \mathrm{g} / \mathrm{L}$ & 195 & 1.988 & $<0.001$ & 0.049 & 0.114 & 0.410 & 266.6 & 15 & 1.0 \\
\hline $\mathrm{V}$ & $\mu \mathrm{g} / \mathrm{L}$ & 195 & 2.380 & $<0.011$ & $<0.011$ & $<0.011$ & 0.891 & 45.37 & - & - \\
\hline $\mathrm{Zn}$ & $\mu \mathrm{g} / \mathrm{L}$ & 195 & 9.305 & $<1.591$ & $<1.591$ & $<1.591$ & $<1.591$ & 454.8 & 3000 & - \\
\hline $\begin{array}{l}\text { Conduc- } \\
\text { tivity }\end{array}$ & $\mu \mathrm{S} / \mathrm{cm}$ & 199 & 457.1 & 15.00 & 178.0 & 314.0 & 549.0 & 2280 & - & - \\
\hline TDS & $\mathrm{mg} / \mathrm{L}$ & 198 & 176.2 & 4.963 & 51.77 & 98.42 & 178.2 & 1454 & $1200^{*}$ & 1.0 \\
\hline Turbidity & NTU & 199 & 14.30 & 0 & 0.237 & 0.793 & 3.303 & 629.7 & $0.1^{*}$ & 90 \\
\hline $\mathrm{pH}$ & & 199 & 6.32 & 3.69 & 5.67 & 6.43 & 6.98 & 8.88 & $\begin{array}{l}6.5- \\
8.5^{*}\end{array}$ & 53 \\
\hline
\end{tabular}

*Recommendation based on aesthetic considerations such as taste and colour.

${ }^{a}$ Taste is often affected (at $300 \mu \mathrm{g} / \mathrm{L}$ ) before WHO health guideline is reached, which is why many prefer to use the taste guideline value.

${ }^{b}$ No health based guideline value is set, however values less than $500 \mathrm{mg} / \mathrm{L}$ are recommended due to damage to gastrointestinal effects. 
Final author submission:

657 List of Figures

658 Figure 1 Map of Ghana with regions and sample points marked. Locations tested that did not exceed 659 the WHO guideline value for $\mathrm{As}, \mathrm{B}, \mathrm{Cl}, \mathrm{F}^{-}, \mathrm{Fe}, \mathrm{Mn}, \mathrm{NO}_{3}{ }^{-}, \mathrm{Pb}$ or $\mathrm{U}$ were marked with an open circle, 660 locations exceeding the WHO guideline were marked according to the legend in the map. 661

662 Figure 2 Cumulative frequency (\%) versus $\mathrm{pH}$. The dotted lines mark the recommended pH range.

663

664 Figure 3 Cumulative frequency (\%) versus turbidity (NTU), conductivity $(\mu \mathrm{S} / \mathrm{cm})$ and TDS (mg/L).

665

666 Figure 4 Cumulative frequency (\%) versus concentration $(\mu \mathrm{g} / \mathrm{L})$ on $\log$ axis for $\mathrm{Pb}$, As and $\mathrm{U}$ (top) and $667 \mathrm{Fe}, \mathrm{Mn}, \mathrm{B}$ and $\mathrm{F}^{-}$(below). The dotted line indicates the WHO guideline.

668

669 Figure 5 Cumulative frequency (\%) versus concentration $(\mathrm{mg} / \mathrm{L})$ on $\log$ axis for $\mathrm{Al}$ (top); then $\mathrm{Cl}, \mathrm{NO}_{3}{ }^{-}$ 670 and $\mathrm{SO}_{4}{ }^{2-}$ (middle) and finally $\mathrm{Ca}, \mathrm{K}, \mathrm{Mg}$ and $\mathrm{S}$ (bottom). The dotted line indicates the WHO guideline 671 where available.

673 Figure 6 Comparison between boreholes $(\mathrm{BH})$ and wells: percentage of source type with samples above 674 the WHO guideline for $\mathrm{Mn}, \mathrm{Fe}, \mathrm{F}^{-}, \mathrm{Cl} \mathrm{NO}_{3}{ }^{-}$and turbidity.

676 Figure 7 Distribution of water charge systems (charge based on water usage, annual charge, no charge) 677 out of the 220 water sources visited. 


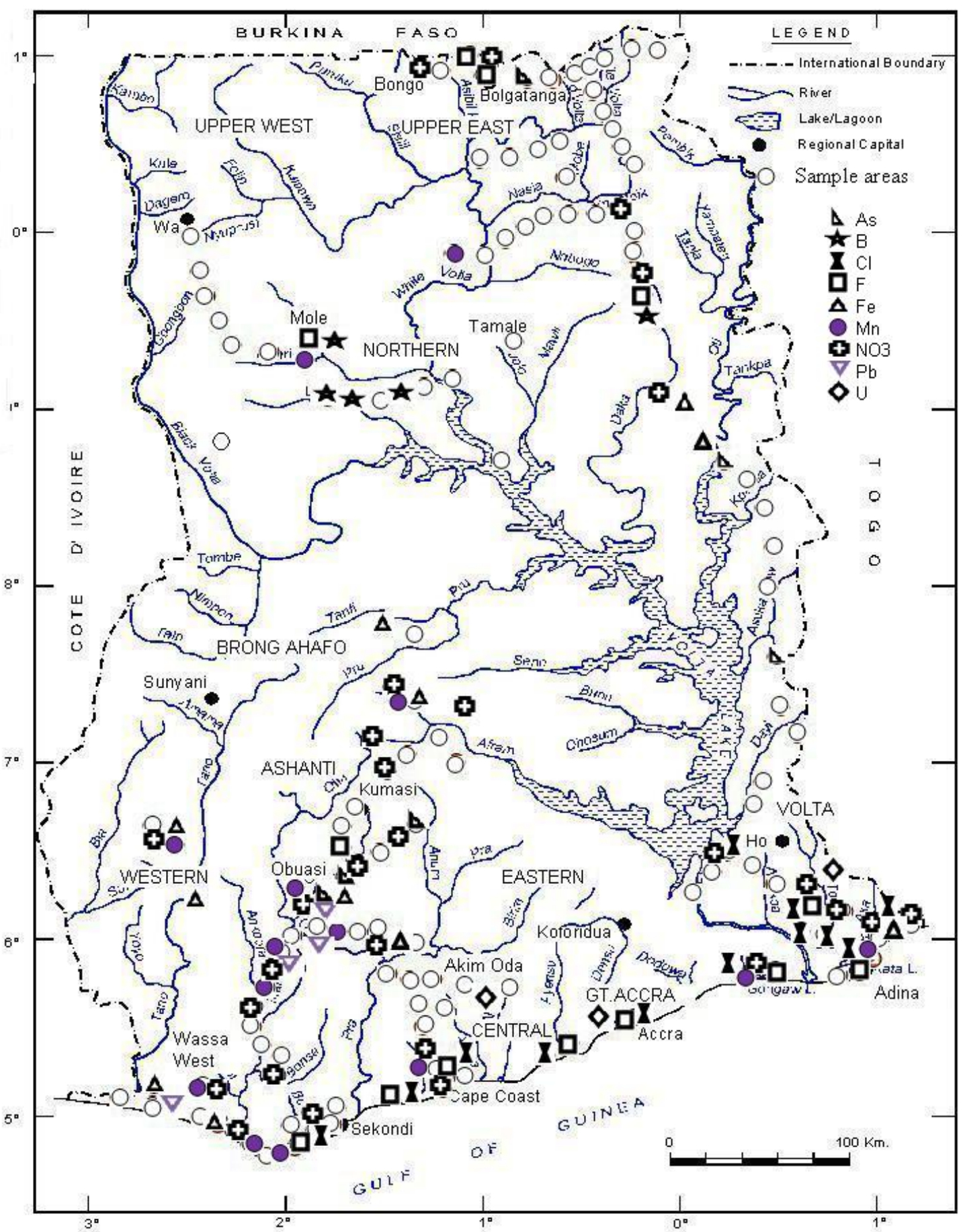

681 Figure 1

682 
Final author submission:

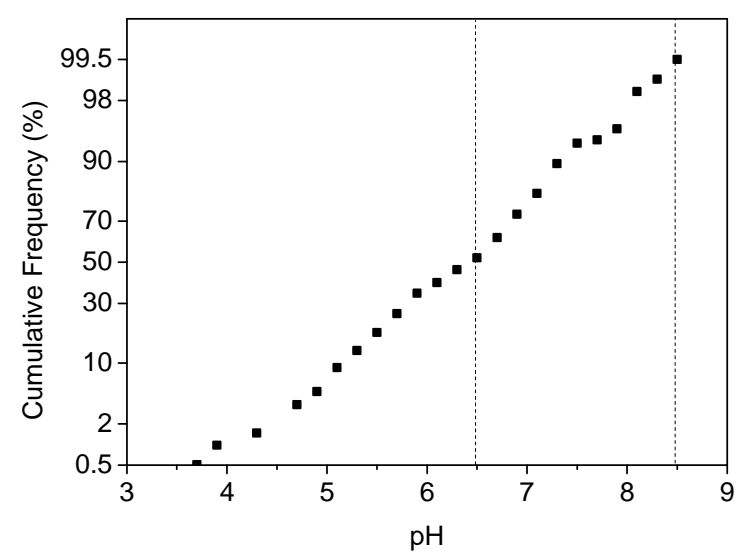

683

684 Figure 2
Science of the Total Environment 408 (2010) 2378-2386

685 
Final author submission:

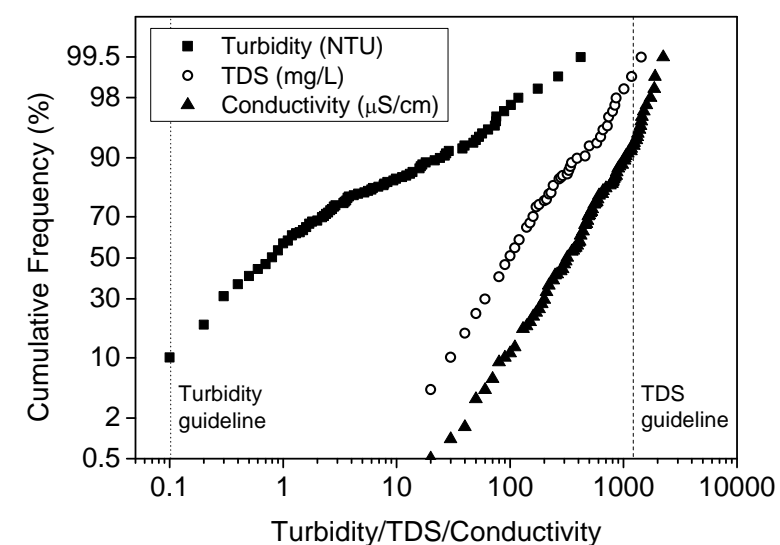

686

687

Figure 3

688 

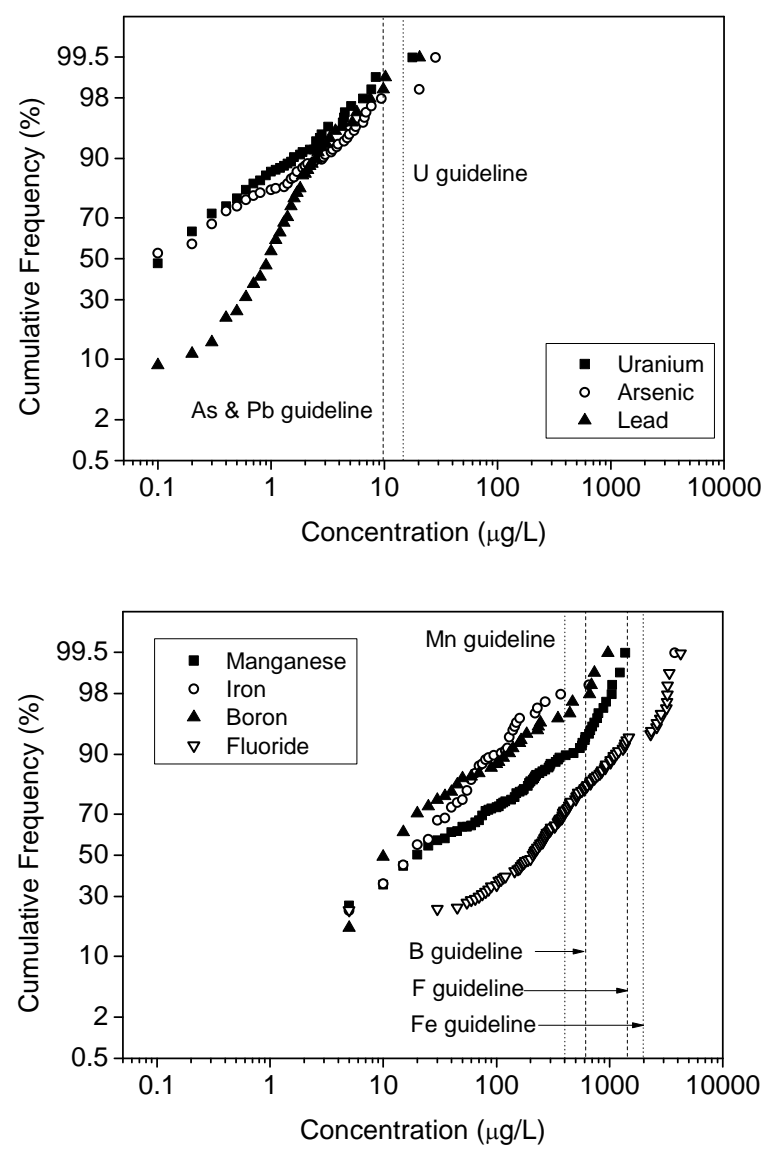

689

690 Figure 4 
Final author submission:
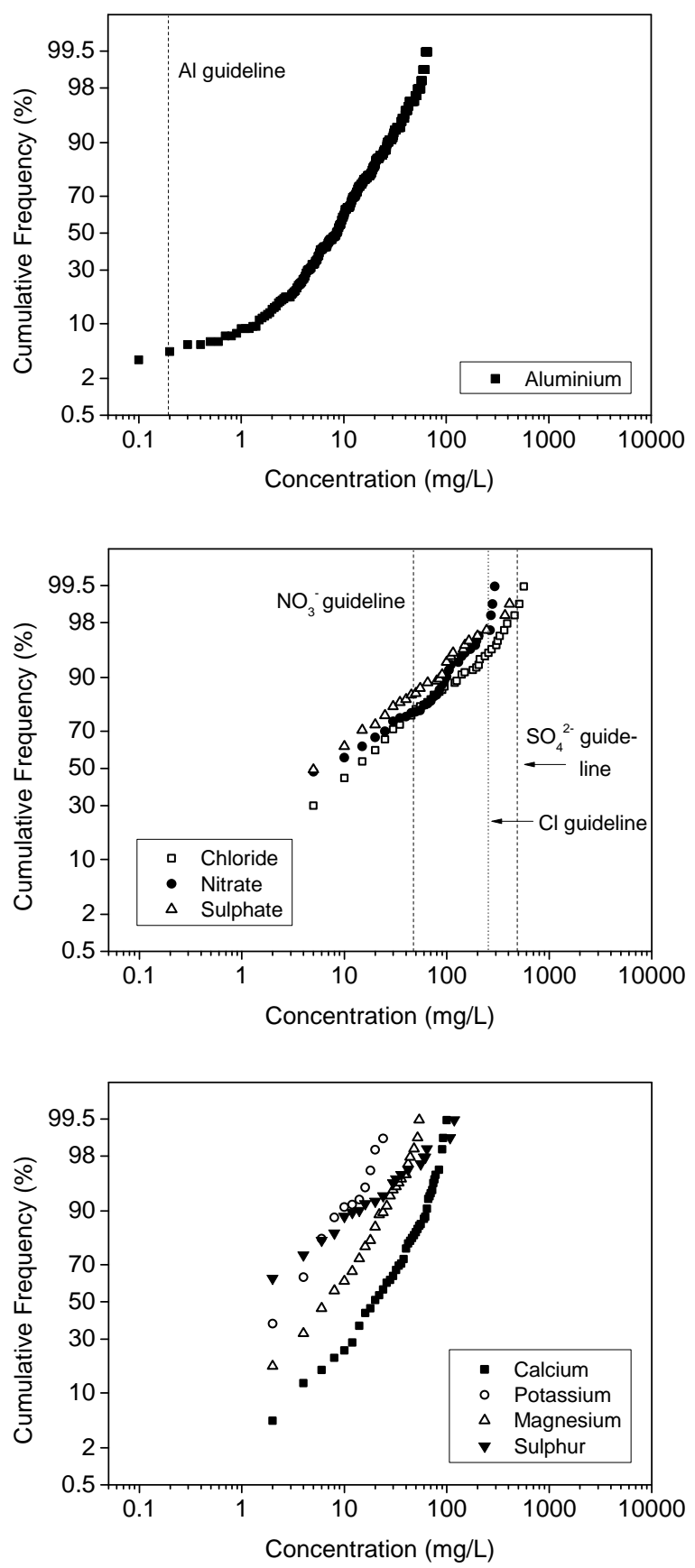

691

692 Figure 5

693
Science of the Total Environment 408 (2010) 2378-2386 
Final author submission:

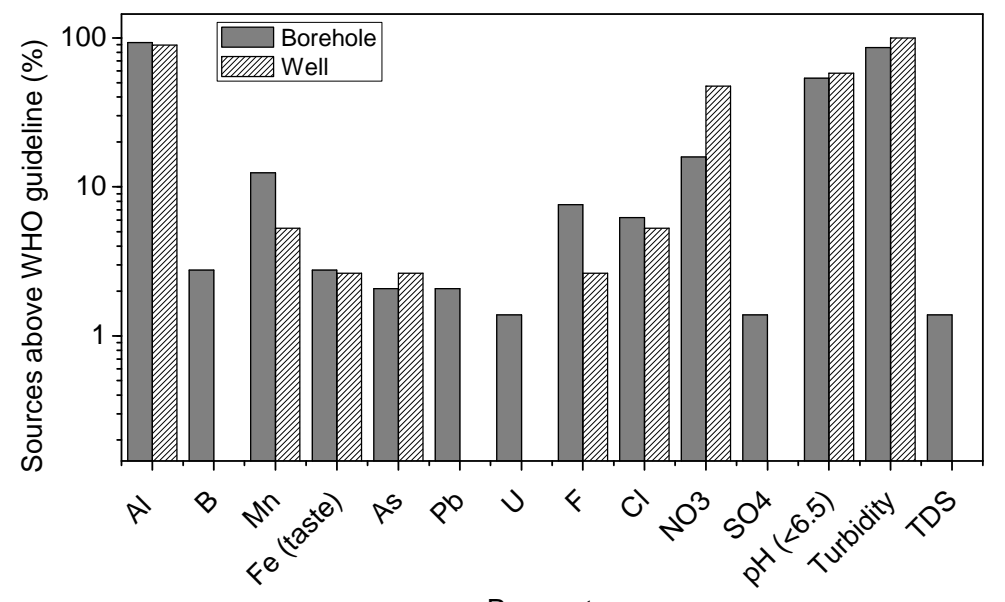

694

695 Figure 6

696 
Final author submission:

697

698

699

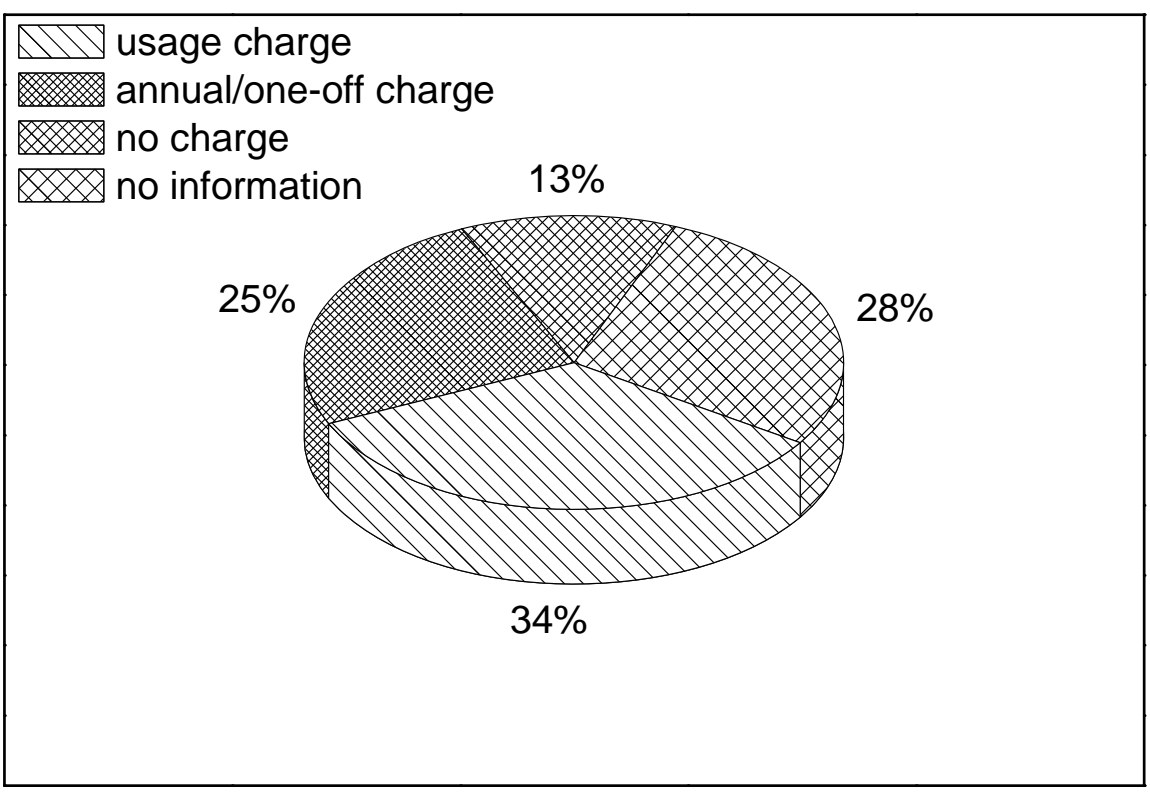

$700 \quad$ Figure 7 